\title{
Kinetic Study of Anaerobic Digestion of Ketchup Industry Wastewater in a Three-stages Anaerobic Baffled Reactor (ABR)
}

\author{
Indro Sumantri*, B. Budiyono, P. Purwanto \\ Doctoral Program of Chemical Engineering, Faculty of Engineering, Diponegoro University, \\ Semarang, Indonesia \\ Department of Chemical Engineering, Faculty of Engineering, Diponegoro University, \\ Semarang, Indonesia
}

Received: 25th June 2018; Revised: 17th January 2019; Accepted: $23^{\text {th }}$ January 2019; Available online: 30th April 2019; Published regularly: 1st August 2019

\begin{abstract}
The anaerobic digestion of the ketchup industry's wastewater in a three-stage $60 \mathrm{~L}$ capacity baffled reactor has been studied. The effect of concentrations of the initial chemical oxygen demand (2727.3$12086.7 \mathrm{mg} / \mathrm{L}$ ), on the ABR performance and kinetic models were investigated. The ABR performance was evaluated by measuring the concentrations of each compartment of the COD, calculating its percentage removal, and the acquired data were fitted to the kinetic models. From the initial input, the three-stage ABR successfully removed $90 \%$ of COD, for the initial COD until the concentration was $5324.6 \mathrm{mg} / \mathrm{L}$ it achieved stationary phase with HRT 5-10 days, while for initial COD until the concentration was $12086.7 \mathrm{mg} / \mathrm{L}$ is attained, the stationary was at 10 days. The kinetic model of second order Grau was suitable for the data, with $k_{2}$ of $0.6061 \mathrm{~d}^{-1}$ and $\mathrm{R}^{2}$ of 0.9955 . Copyright (C) 2019 BCREC Group. All rights reserved
\end{abstract}

Keywords: Ketchup; Kinetic of anaerobic digestion; Three-Stages ABR; Anaerobic Baffled Reactor

How to Cite: Sumantri, I., Budiyono, B., Purwanto, P. (2019). Kinetic Study of Anaerobic Digestion of Ketchup Industry Wastewater in a Three-stages Anaerobic Baffled Reactor (ABR). Bulletin of Chemical Reaction Engineering \& Catalysis, 14 (2): 326-335 (doi:10.9767/bcrec.14.2.2838.326-335)

Permalink/DOI: https://doi.org/10.9767/bcrec.14.2.2838.326-335

\section{Introduction}

The food industry is one of the fastest growing industries in Indonesia, and one of its products is the sauce, which can be produced using both modern and traditional methods. Products of sauce (ketchup, tomato or chili), have huge potential market values of up to 1.5 billion rupiahs. This is mainly due to the changes in people's lifestyles, which demands practicality and efficiency in consuming food [1].

\footnotetext{
* Corresponding Author.

E-mail: indrotekim@yahoo.com (I. Sumantri)

Telp: +6224-7460058 Fax: +6224-76480675
}

Ketchup is a complementary food in Indonesian tradition, it is a condiment in the form of a black-colored liquid, with a sweet or salty taste. The most popular type of soy sauce in Indonesian cuisine is "kecap manis" or sweet soy sauce, which has a thick syrupy consistency. One of the familiar ketchup brands is "Superindo", which is produced by Superindo, one of the giant retailers in Indonesia. It comprises of palm, sugar, water, soybean, salt, spices, sodium benzoate, and monosodium glutamate.

However, the linear increase in the production of ketchup increases the generation of wastewater. The main raw material for the production of ketchup is soybean, which leads to 
the generation of biodegradable wastes. The wastewater from the processes has high organic content, with a COD value higher than $4.5 \mathrm{~g} / \mathrm{L}$, which confirms the characteristics of food industry wastes. High protein content in soybean affects the characteristics of the wastewater, with high chemical oxygen demand (COD) (10-20 g/L), and biological oxygen demand (BOD) values [2].

Some researchers have conducted wastewater treatment using $\mathrm{ABR}$ with different number of baffles, which are: Boopathy [3] with 2, 3, and 4 baffles, Feng et al. [4] with 6 baffles, Krishna et al. [5] with 8 baffles, Ghaniyari-Benis et al. [6] with 3 baffles, Ahamed et al. [7] with 2 baffle, Hahn et al. [8] with 4 baffles, Aqaneghad et al. [9] with 5 baffles, and Gulhane et al. [10] with 3 baffles. The number of baffles in the ABR provides better physical contacts between the wastewater and the activated sludge. Less study conducted on substrate removal rate evaluation using kinetic model of the firstorder, Monod, Stover-Kincannon, and that of the second order Grau, for ketchup's wastewater. Therefore, the objective of this paper is to investigate the performance of ABR with three baffles in the ketchup's wastewater treatment, and the dominant kinetic model to this wastewater.

\section{Materials and Methods}

\subsection{Materials}

\subsubsection{Wastewater preparation}

The synthetic wastewater for the experiment was obtained from the dissolution of ketchup in distilled water. The said measurement of ketchup (2 g/200 mL distilled water) contains COD (11,244.99-13,540.15 mg/L), BOD (6,596.70-6,937.79 mg/L), total solid $(4,987.18-7,011.50 \mathrm{mg} / \mathrm{L})$, total suspended solid (6.99- 8.54 mg/L), and total dissolved solid $(4,978.64-7,003.63 \mathrm{mg} / \mathrm{L})$. It can be used to calculate the requirements of the ketchup to volume, $60 \mathrm{~L}$ and the COD (2727.3-12086.7 $\mathrm{mg} / \mathrm{L})$.

\subsubsection{Sludge preparation}

The anaerobic sludge for the experiment was collected from an anaerobic reactor of the Centralized wastewater Treatment Plant, for small-scale industries at Lamper Tengah, Semarang Municipality, and Central Java, Indonesia. The sludge was taken from the bottom of the anaerobic reactor by using water sampler. The sludge's conditioning was carried out using synthetic wastewater with $2 \mathrm{~g} / \mathrm{L}$ concentration of sucrose, the sludge was set up using the $\mathrm{pH}$ of $7.5, \mathrm{Ca}^{2+}$ ion of $40 \mathrm{mg} / \mathrm{L}$, addition of $\mathrm{N}$ and $\mathrm{P}$ macro nutrients with ratio (COD:N:P) of 300:5:1, and micro nutrients with the composition (per g COD) [12] : 500 $\mu \mathrm{g}$ of $\mathrm{Co}, 300 \mu \mathrm{g}$ of $\mathrm{Cu}, 4000 \mu \mathrm{g}$ of $\mathrm{Fe}, 150 \mu \mathrm{g}$ of Mo, $6000 \mu \mathrm{g}$ of $\mathrm{Ni}$, and $600 \mu \mathrm{g}$ of $\mathrm{Zn}$. This conditioning was run for a month with flow rate of $20 \mathrm{~L} /$ day to swipe the light density of the sludge from the ABR [13].

\subsubsection{The ABR dimension}

A $60 \mathrm{~L} \mathrm{ABR}$ bio-reactor with transparent Plexiglas sheet was designed and fabricated in to three pairs, the down flow, up, and sample ports. The ABR dimension has $60 \mathrm{~cm}$ length, $25 \mathrm{~cm}$ width, $40 \mathrm{~cm}$ height, $10 \mathrm{~cm}$ distance between baffles, and $1.5 \mathrm{~cm}$ distance between baffle and bottom reactor. The ABR was sectioned into three equal compartments, and each has a pair of down and up flow baffles (hanging and standing baffles), and sample ports (Figure 1).

The temperature difference between inside and outside the reactor, due to the changes in the temperature during the day and night, was observed to be less than $3^{\circ} \mathrm{C}$. Hence, the reactor did not require further cooling or heating in order to maintain the temperature. A peristaltic pump was used to introduce the wastewater to the ABR system, this pump was chosen because its flow rate can be set to the required range of volume, or time.

\subsection{Methods}

\subsubsection{Procedure of wastewater digestion}

Experiments were conducted with peristaltic pump using the volumetric feed rate of 20 $\mathrm{L} /$ day, initial $\mathrm{pH}$ of 7-7.5, and additional trace elements per gram COD (Co: $500 \mu \mathrm{g}, \mathrm{Cu}: 300$ $\mu \mathrm{g}, \mathrm{Fe}: 4000 \mu \mathrm{g}$, Mo: $150 \mu \mathrm{g}, \mathrm{Ni}: 6000 \mu \mathrm{g}$, and $\mathrm{Zn}: 600 \mu \mathrm{g})$. The experiments were carried out at room temperature, and atmospheric pressure, with calcium ion $(40 \mathrm{mg} / \mathrm{L})$, and MLSS $(7,200 \mathrm{mg} / \mathrm{L})$. The research variable was the initial COD concentration (ranges of 2727.3-12086.7 mg/L). Samples were taken from each compartment of the ABR ports. For the first day, the samples were taken only from the first port. On the Second day, they were from the first and second ports, and on the third day and beyond that, they were taken from the three ports. $\mathrm{Pa}$ rameters observed during this research are $\mathrm{pH}, \mathrm{COD}$, and total suspended solid (TSS). The 
selection of the COD as the main parameter is based on the quantity of the organic material [14].

\section{Results and Discussions}

\subsection{Reactor Performance}

The results of the experiments corresponding to the initial COD concentrations are shown in Table 1 . The best ABR operation conditions were observed at the OLR of 5.342 g/L.d. In this operation, a steady-state condition with the best reactor performance was assumed, and the experiments were conducted in mixed conditions for kinetics evaluation. According to Table 1, the maximum COD removal efficiency obtained was up to $98.16 \%$ (corresponding OLR $=5.342$ g COD/L.d) [15].

\subsection{Performance of Compartments}

Figure 2 indicates the percentage of COD removal for the various initial COD concentrations. The slope indicates the rate of COD removal for the first-two initial COD concentrations $(2727.3$ and $5342.6 \mathrm{mg} / \mathrm{L})$, the curves were closed and higher than that of the lasttwo data (8113.7 and $12086.7 \mathrm{mg} / \mathrm{L}$ ). The first compartment consists of the first contact between the wastewater and activated sludge, this plays an important role in the removal of organic substances. Food products usually have high organic substances and high degradable substances. The result of the COD removal indicates the good performance of the activated sludge in decomposing the organic substances into simpler forms. Carbohydrate, lipid, and protein exhibit high degradation rates, and it has major influence on their kinetic values. In acidogenesis, the soluble monomers are converted into simple organic compounds, and are attacked by acetogenic bacteria:

Acidogenesis :

$$
\begin{aligned}
& \mathrm{C}_{6} \mathrm{H}_{12} \mathrm{O}_{6}+2 \mathrm{H}_{2} \rightarrow 2 \mathrm{CH}_{3} \mathrm{CH}_{2} \mathrm{COOH}+2 \mathrm{H}_{2} \mathrm{O} \\
& \mathrm{C}_{6} \mathrm{H}_{12} \mathrm{O}_{6} \rightarrow 2 \mathrm{CH}_{3} \mathrm{CH}_{2} \mathrm{OH}+2 \mathrm{CO}_{2}
\end{aligned}
$$

Acetogenesis :

$$
\begin{aligned}
\mathrm{CH}_{3} \mathrm{CH}_{2} \mathrm{COO}^{-} & +3 \mathrm{H}_{2} \mathrm{O} \rightarrow \mathrm{CH}_{3} \mathrm{COO}+\mathrm{H}^{+} \\
& +\mathrm{HCO}_{3}+3 \mathrm{H}_{2}
\end{aligned}
$$

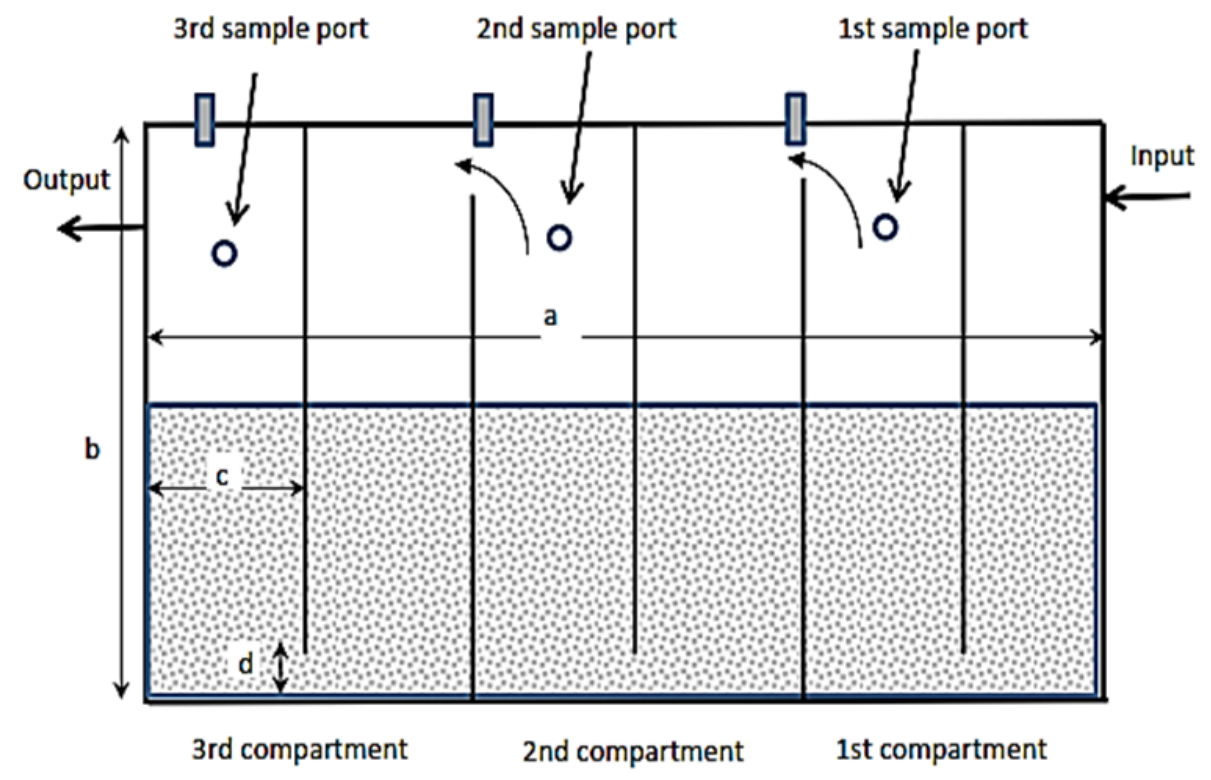

Figure 1. Diagram of the anaerobic baffled reactor $(A B R)$ and its baffles with dimensions $(\mathrm{cm}) \mathrm{a}=60$ $\mathrm{cm} ; \mathrm{b}=40 \mathrm{~cm} ; \mathrm{c}=105 \mathrm{~cm} ; \mathrm{d}=1.5 \mathrm{~cm}$; wide: $25 \mathrm{~cm}$ [13]

Table 1. Typical operation conditions of ABR at MLSS of $6000 \mathrm{mg} / \mathrm{L}$ and HRT of 1 day

\begin{tabular}{ccccc}
\hline No & $\begin{array}{c}\text { OLR } \\
(\mathrm{g} / \mathrm{L} . \mathrm{d})\end{array}$ & $\begin{array}{c}\mathrm{pH} \text { (first to third com- } \\
\text { partments) }\end{array}$ & $\begin{array}{c}\text { COD removal } \\
(\%)\end{array}$ & $\begin{array}{c}\text { Effluent TSS } \\
(\mathrm{mg} / \mathrm{L})\end{array}$ \\
\hline 1 & 2.7273 & $7.6-7.1$ & 97.62 & 3.7 \\
2 & 5.342 & $6.8-7.2$ & 98.16 & 14.4 \\
3 & 8.1137 & $7.1-7.3$ & 97.59 & 26.7 \\
4 & 12.086 .7 & $76.9-7.2$ & 96.89 & 42.8 \\
\hline
\end{tabular}




$$
\begin{aligned}
& \mathrm{C}_{6} \mathrm{H}_{12} \mathrm{O}_{6}+2 \mathrm{H}_{2} \mathrm{O} \rightarrow 2 \mathrm{CH}_{3} \mathrm{COOH}+2 \mathrm{CO}_{2}+4 \mathrm{H}_{2}(4) \\
& \mathrm{CH}_{3} \mathrm{CH}_{2} \mathrm{OH}+2 \mathrm{H}_{2} \mathrm{O} \rightarrow \mathrm{CH}_{3} \mathrm{COO}+2 \mathrm{H}_{2}+\mathrm{H}^{+}(5) \\
& 2 \mathrm{HCO}_{3}+4 \mathrm{H}_{2}+\mathrm{H}^{+} \rightarrow \mathrm{CH}_{3} \mathrm{COO}+4 \mathrm{H}_{2} \mathrm{O}
\end{aligned}
$$

There was no lag-phase for the activated sludge to indicate successful adaptation of the microorganism to the wastewater, or the acclimatization condition of the activated sludge was sufficient to decompose organic substances. It indicates that the soluble mate-
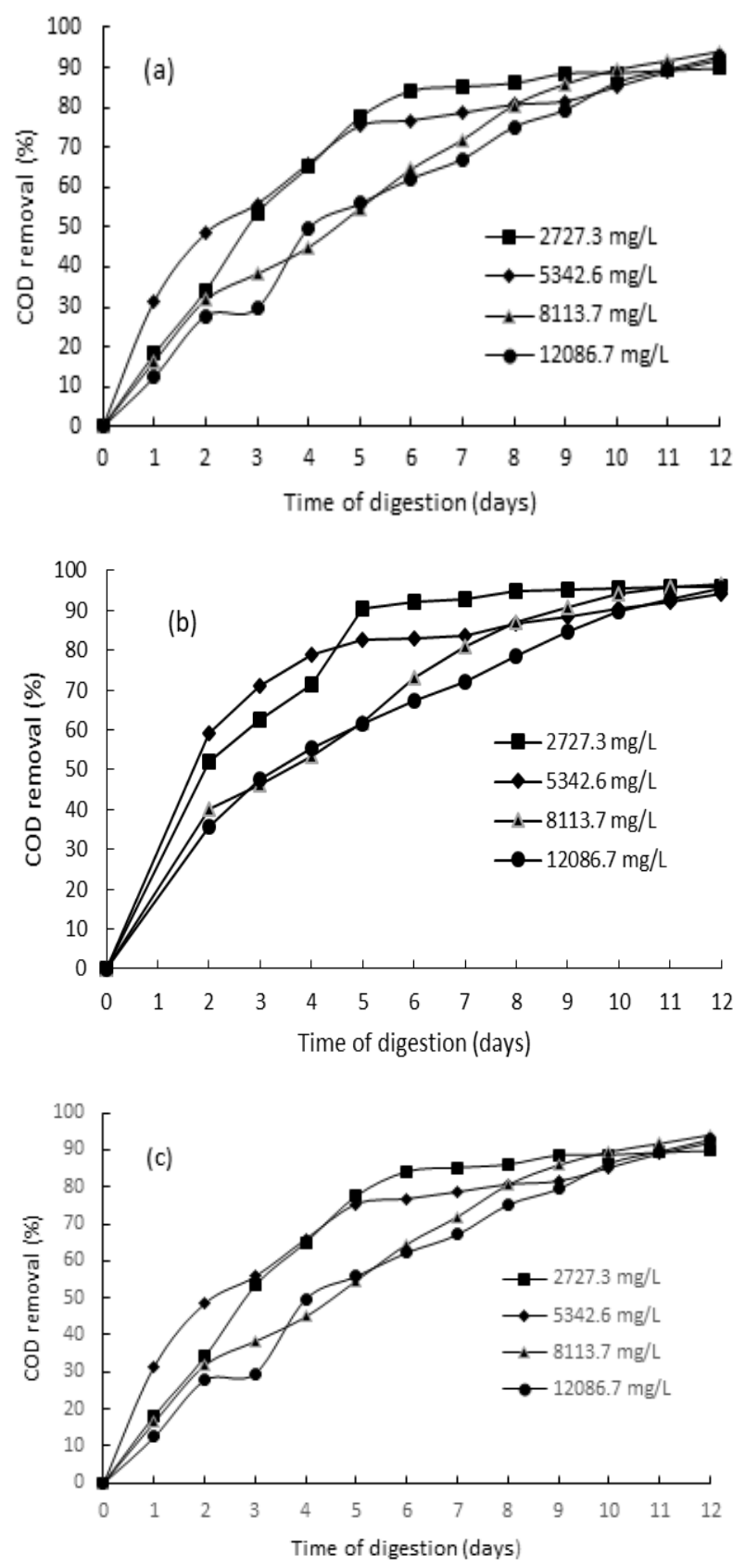

Figure 2. Performance of the compartments to the COD removal (a). First compartment, (b). Second compartment and (c). Third compartment rial in the liquid phase of the substrates was quickly consumed by the anaerobic microorganisms [16]. Food-grade waste is characterized as having high degrees of readily degradable materials as well as digestibility. For the first two COD concentrations (2727.3 and $5342.6 \mathrm{mg} / \mathrm{L}$ ), the degradation occurred in high rate for six days of digestion, resulting to more than $85 \%$ COD removal. Microorganisms in the activated sludge were able to decompose the organic substances in the wastewater. During the first contact, abundant organic biodegradable substances were available in the wastewater, and it resulted to high rate of degradation [17,18]. The stationary curve resulted after 6 days digestion time, the graph describes the additional time of digestion obtained during insignificant increase in the COD removal.

At the COD concentration of 8113.7 and $12086.7 \mathrm{mg} / \mathrm{L}$, increasing the load of the wastewater affected the degree of decomposition of the organic substances. The activated sludge can reduce the COD of wastewater but the rate was lower than that of the previous load. The curve of 8113.7 and 12086.7 $\mathrm{mg} \mathrm{COD} / \mathrm{L}$ indicated that the rate of removal was lower than that of 2727.3 and $5342.6 \mathrm{mg}$ COD/L. The stationary curve had not been achieved yet until the twelfth day. In the first compartment, increasing the COD concentration will also increase the number of degradable substances, but the microorganisms in the activated sludge has limited degradation ability. The degree of removal was lower than that of previous load. At the eleventh day, the four curves were very close, increasing the load of the organic substances, required longer HRT to reach the degradation [7].

For the second compartment, the degree of removal was lower than that of the first compartment, large quantity of degradable organic substances had been degraded in the first compartment. The remaining organic materials would be continuously degraded in the second compartment. With low COD content (2727.3 and 5342.6 $\mathrm{mg} \mathrm{COD/L}$ ), the stationary curve has been achieved during five to six days of digestion time, the degree of removal is $82-90 \%$. While for 8113.7 and $12086.7 \mathrm{mg}$ COD/L, the curves had not indicated the stationary condition, which shows that the degradation of organic materials has not finished yet. With excessive increase in the concentration, the removal efficiency decreased, which might be attributed to the extra concentration of volatile fatty acids in the reactor 
[19]. The total removal in the second compartment was lower than that in the first, due to the lesser quantity of organic degradable materials in the waste water.

The third compartment is a zone used to accomplish the degradation of the organic substances in the anaerobic process. The final removal of these various contents was above $95 \%$. This final COD concentration is sufficient to further process the wastewater (aerobic), in other to fulfill the standard regulation. This result of the COD removal is higher than other researchers using ABR [310].

It can be said that three stages of $A B R$ is enough to treat the Indonesian wastewater for the production of the tradition food (Ketchup). The baffles' design with equal intervals is easy to construct, and also limited to area requirements.

\subsection{Kinetic Model}

\subsubsection{First order kinetic model}

First order kinetic model states that the rate of substrate with variation concentration in a reactor with respect to time can be expressed as follows [20,21]:

$$
-\left(\frac{d S}{d t}\right)=\frac{Q}{V} S-\left(\frac{Q}{V}\right) S_{0}-k_{1} S
$$

where, $S_{0}$ and $S$ are substrate concentrations in influent and effluent (mg COD/L) respectively, $Q$ is flowrate to reactor $(\mathrm{L} / \mathrm{d}), V$ is reactor total volume $(\mathrm{L}), \theta_{H}$ is hydraulic retention time (HRT) or (V/Q), and $k_{1}$ is first order constant rate. Under steady-state condition, the rate of substrate concentration is negligible and the Equation (7) reduced to:

$$
\frac{S-S_{0}}{\theta_{H}}=k_{1} S
$$

The value of $k_{1}$ is determined by plotting of $\left(S_{0}-S\right) / \theta_{H}$ and effluent substrate concentration $S$ of Equation (8). The value of $k_{1}$ and regression were calculated from the data acquired from the experiments. Figure 3 shows the graph obtained by plotting of $\left(S_{0}-S\right) / \theta_{H}$ and $S$. It can be seen that the value of $\mathrm{k}_{1}$ obtained from the slope of linear line of the graph is $0.3997 /$ day and regression value $\left(R^{2}\right)$ is 0.9738 .

\subsubsection{Monod kinetic model}

Monod model is proposed by theory that substrate concentration around microorganism is also significantly considered in evaluation of kinetic parameter [22]. In the 1949, Monod proposed an equation to indicate the relation of rate of specific growth and rate limiting substrate concentration.

$$
\begin{aligned}
& \frac{d S}{d t}=-\frac{\mu_{\max } X}{Y} \frac{S}{K_{s}+S}+\frac{K_{d} X}{Y} \\
& \mu=\mu_{\max }\left(\frac{S}{K_{3}+S}\right)
\end{aligned}
$$

$\mu$ is specific growth rate $\left(\mathrm{d}^{-1}\right), S$ is substrate concentration (mg COD/L), $\mu_{\max }$ is rate of maximum growth when substrate unlimited $\left(\mathrm{d}^{-1}\right)$, $K_{s}$ : half saturation constant $(\mathrm{mg} / \mathrm{L}), X$ is biomass concentration in reactor $(\mathrm{mg} / \mathrm{L})$, and $Y$ is yield coefficient (mg VSS/mg COD). Under the steady-state, it can be assumed that effluent biomass concentration is negligible $(d X / d t=0$ and $-d S / d t=0)$.

$$
\mu=\frac{1}{\theta_{C}}+K_{d}
$$

$K_{d}$ is decay coefficient and $\theta_{C}$ is mean cell residence time (ratio of total biomass in the reactor to the biomass wasted for a given time, time represent the average time).

$$
\theta_{C}=\frac{V X}{Q X_{E}}
$$

Combination and rearrangement of Equations (11) and (12), the kinetic parameter $Y$ and $K_{d}$ can be obtained :

$$
\frac{S_{0}-S}{\theta_{H} X}=\frac{1}{Y}\left(\frac{1}{\theta_{C}}\right)+\frac{1}{Y+K_{d}}
$$

Regression coefficient and kinetic parameter can be obtained by plotting curve of $\left[\left(S_{0^{-}}\right.\right.$

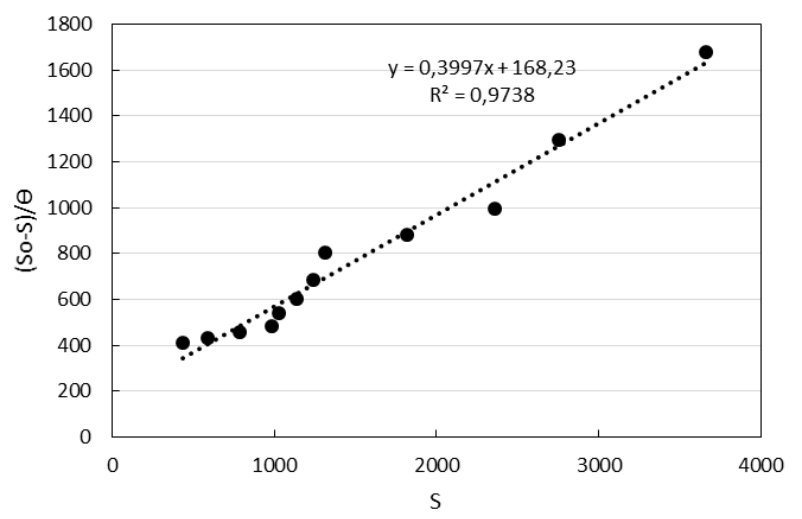

Figure 3. Graph of regression value of first order kinetic model 
$\left.S) /\left(\theta_{H} X\right)\right]$ to the $\left(1 / \theta_{C}\right)$. Figure 4 shows the regression graph of the Monod kinetic model. The regression value is 0.8351 , the slope is 11.963 $(=1 / Y)$, hence, the of $Y$ is $0.0836 \mathrm{mg} \mathrm{VSS} / \mathrm{mg}$ COD, while the intercept value is 0.3892 $\left(=1 /\left(Y+K_{d}\right)\right.$ and the value of $K_{d}$ is $2.4858 /$ day.

In order to determine the value of $K_{s}$ and $\mu_{\max }$, introducing Equation (13) to Equation (12) to obtain Equation (8).

$\frac{\theta_{C}}{1+K_{d} \theta_{C}} S=\frac{K_{s}}{\mu_{\max }}+\frac{S}{\mu_{\max }}$

Figure 5 shows the graph of $\left(S \theta_{C}\right) /\left(1+\theta_{C} K_{d}\right)$ to the $S$ based on the data acquisition of the experiments. The slope is the value of $1 / \mu_{\max }$ and the intercept is for constant of $K_{s} / \mu_{\max }$. Based on the Figure 5 , the value of slope is 0.4029 , hence the $\mu_{\max }$ is $2.482 / \mathrm{d}$ and the value of intercept is 4.3448 and the value of $K_{s}$ is $-10.7838 / d$ with regression coefficient is 1 .

\subsubsection{Stover-Kincannon kinetic model}

Stover-Kincannon model [23] is a mathematical model which mostly applied to determine the kinetic constant of Up-flow Anaerobic Sludge Blanket (UASB) reactor. Firstly, the model was set up for Rotating Biological Contactor (RBC). Stover-Kincannon provided flexibility to predict rate of degradation of the independent substrate of kinetic reaction (zero order, first order or second order) at the various organic loading [24]. This model assumed that substrate removal rate as the function of substrate loading rate.

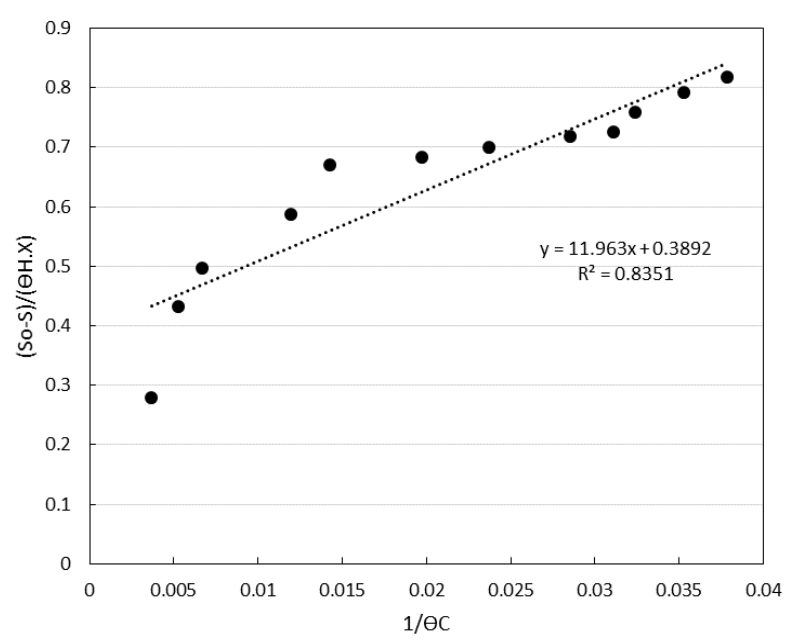

Figure 4. Graph of Monod kinetic model to determine the values of $Y$ and $K_{d}$
Stover-Kincannon derived the kinetic model for biofilm reactor based on the total organic loading rate. The modified model of StoverKincannon described total organic loading rate as the primary parameter to explain the kinetic of an Anaerobic Filter (AF) by means of organic substance removal and methane production [25]. Stover-Kincannon model was applied to analyze the reactor removal efficiency at the fixed bed region with different organic loading rate [26]. The equation of Stover-Kincannon can be written as :

$$
\begin{aligned}
& \frac{d S}{d t}=\frac{Q}{V}\left(S_{0}-S\right) \\
& \frac{d S}{d t}=U_{\max }\left(\frac{Q S_{0}}{V}\right)=\left(K_{B}+\left(\frac{Q S_{0}}{V}\right)\right)
\end{aligned}
$$

$U_{\max }$ is rate of maximum substrate utilization (gL/d), $K_{B}$ is saturation constant (g/L.d). Rate of substrate removal $(d S / d t)$ in Equation (15) can be defined by using Equation (16) into the modified Stover-Kincannon:

$$
\left(\frac{d S}{d t}\right)^{-1}=\frac{V}{Q\left(S_{0}-S\right)}=\frac{K_{B} V}{Q U_{\max } S_{0}}+\left(\frac{1}{U_{\max }}\right)
$$

$U_{\max }$ and $K_{B}$ were obtained from the linear graph of $1 /\left(S_{o}-S\right)$ and $1 / S$ as intercept and slope of the graph [26]. Figure 6 shows the regression coefficient is 0.4276 , the intercept value is $0.0004\left(=1 / U_{\max }\right)$, hence, the value of $U_{\max }$ is $2500 \mathrm{mg} / \mathrm{L}$ and the slope is -0.1245 $\left(=K_{B} . V / Q . U_{\max }\right)$ therefore, the value of $K_{B}$ is 311.25 .

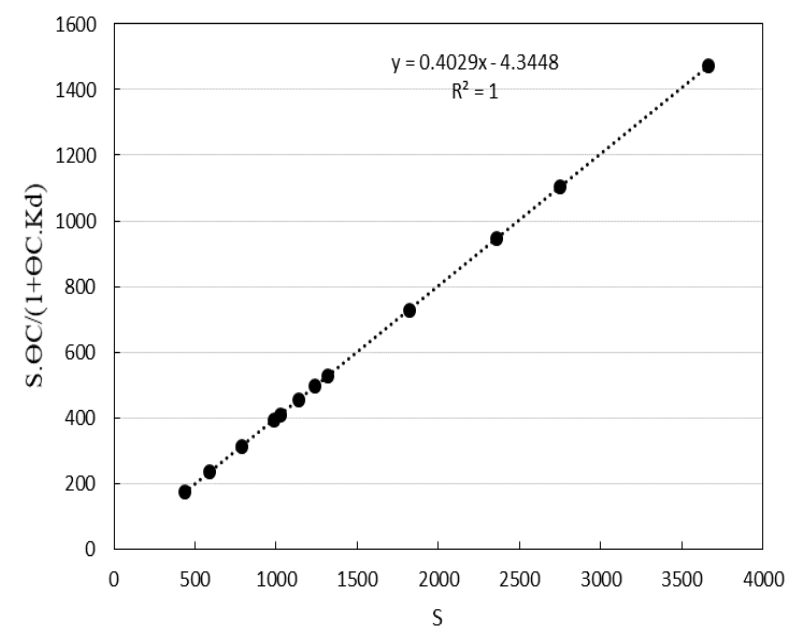

Figure 5. Graph of Monod kinetic model to obtain the values of $\mu_{\max }$ dan $K_{s}$ 


\subsubsection{Second order Grau model}

Second order Grau model [28] was developed to determine the removal of multicomponent substrate by activated sludge [29]. This model was expanded in the basic concept of linear removal of the special case of Monod model. In this model, reaction order was analogous to the order of chemical reaction with constant rate is not limited to integers. Second order chemical kinetic can be written as :

$-\frac{d S}{d t}=k_{2} X\left(\frac{S}{S_{0}}\right)^{2}$

$\frac{S_{0} \theta_{H}}{S_{0}-S}=\theta_{H}+\frac{S_{0}}{k_{2}-X}$

$S_{e}$ is effluent substrate concentration (mg COD/L), $S_{i}$ is influent substrate concentration (mg COD/L), $k_{2}$ is constant of second order substrate removal $(1 / d)$, and $X$ is biomass concentration $(\mathrm{mg} / \mathrm{L})$.

Second order Grau model derived of combining Monod model (Equation (10)) and chemical reaction kinetic (Equation (18)). Figure 7 indicated the linear model of second order Grau model between HRT/E and HRT as :

$$
\frac{S_{0} H R T}{\left(S_{0}-S\right)}=H R T+\frac{S_{0}}{k_{2} X}
$$

$X$ is biomass in the reactor $(\mathrm{mg} / \mathrm{L}), H R T$ is hydraulic retention time (d), and $k_{2}$ is constant of second order rate $(1 / \mathrm{d})$. The term of $\left(S_{0}-S\right) / S$ indicated substrate removal efficiency, $E$ and second term of right side $\left(S_{\mathrm{i}} /\left(k_{2} X\right)\right)$ often assumed as a constant. Hence, the equation :

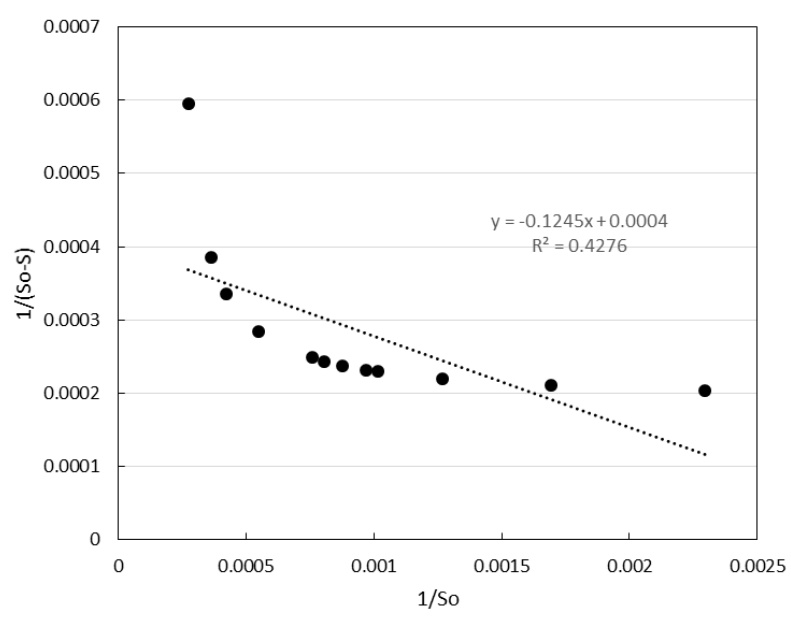

Figure 6. Graph of regression of StoverKincannon model

$$
\frac{S_{i} \theta_{H}}{S_{i}-S_{e}}=a+b \theta_{H}
$$

where $a\left(=S_{i} / k_{2} X_{i}\right)$ for substrate kinetic, $a$ depends on initial concentration of specific substrate $S_{i} . X_{i}$ and $b$ is other constant (dimensionless) with the value approach unity that reflect impossible to achieve the zero value for substrate concentration at given $\theta_{H}$.

Figure 7 shows the linear line regression of second order Grau model by plotting HRT/E and HRT. The value of intercept $(a)$ is $S_{o} / k_{2} . X$ is 2.3675 , hence, the $k_{2}$ is $0.3761 / \mathrm{d}$, while the regression coefficient is 0.9955 . Hence, the formula for predicting substrate concentration in the effluent can be given as [30]:

$$
S=S_{0}-\frac{S_{0} \theta_{H}}{1.4693+0.9064 \theta_{H}}
$$

Result of the calculation of each compartment and overall reactor for four model kinetics is presented in Table 2.

\subsubsection{Model testing}

Kinetic constants of four models are presented in Table 2. These four models were used to determine the output COD exiting the ABR reactor and compares it with the input concentration entering the reactor. Based on the regression coefficient $\left(\mathrm{R}^{2}\right)$ for overall reactor, the second order Grau model is clearly higher than others. Hence, it can be stated that the output values of COD observed in the reactor are more consistent with second order Grau.

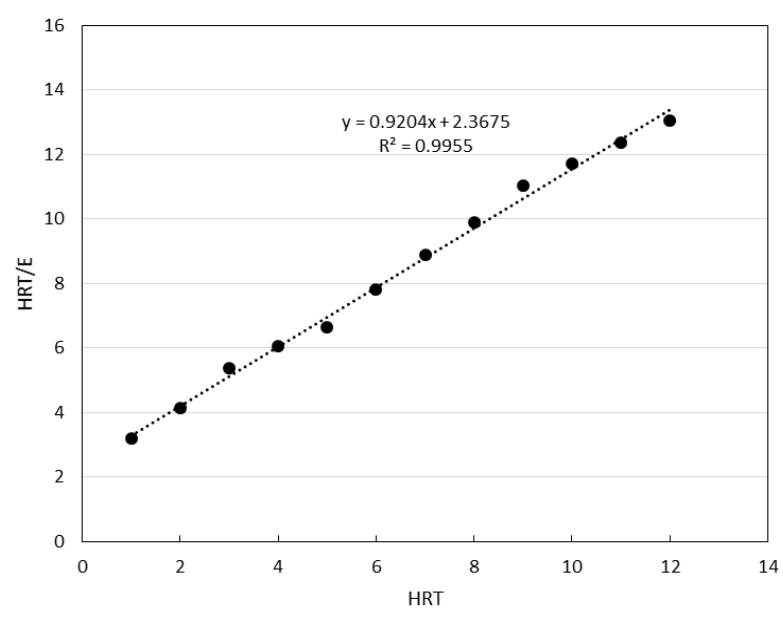

Figure 7. Graph of regression of second order Grau model 


\section{Conclusion}

The performance of ABR, the highest COD removal efficiency was achieved in the first compartment, while for subsequent compartments have lower COD removal efficiency. Based on bacterial kinetics, lower substrate concentration caused lower growth rate. During the initial stage, activity of the seed sludge influenced by environmental change and microbe was needed to adapt to the new situation. Therefore, the COD concentration of the effluent was high, and the total removal efficiency was lower. With the operation of the reactor continuously, the activity of the sludge would be higher, and the COD of the effluent of the was lower. The regression coefficient $\left(\mathrm{R}^{2}\right)$ for four models indicated that second order Grau model has highest value. It means that kinetic models for prediction of effluent substrate concentration of the $\mathrm{ABR}$ at the similar operation conditions represents the experimental data obtained.

\section{Acknowledgments}

The author was gratefully acknowledge to the Directorate of Higher Education, Ministry of Research, Technology and Higher Education of the Republic of Indonesia for providing the financial support during research in Diponegoro University.

Table 2. The values of kinetic parameter for four kinetic models

\begin{tabular}{|c|c|c|c|c|}
\hline Kinetic model & $\begin{array}{c}\text { Anaerobic } \\
\text { compartment }\end{array}$ & Kinetic parameter & Value & $\begin{array}{c}\text { Regression } \\
\text { coefficient } \\
\left(\mathrm{R}^{2}\right)\end{array}$ \\
\hline \multirow[t]{4}{*}{ First order } & Comp-1 & $k_{1}\left(\mathrm{~d}^{-1}\right)$ & 0.3997 & 0.9738 \\
\hline & Comp-2 & $k_{1}\left(\mathrm{~d}^{-1}\right)$ & 0.6719 & 0.9683 \\
\hline & Comp-3 & $k_{1}\left(\mathrm{~d}^{-1}\right)$ & 0.4193 & 0.7632 \\
\hline & Overall ABR & $k_{1}\left(\mathrm{~d}^{-1}\right)$ & 0.6632 & 0.8723 \\
\hline \multirow[t]{16}{*}{ Monod } & Comp-1 & $Y(\mathrm{mg} \mathrm{VSS} / \mathrm{mg} \mathrm{COD})$ & 0.0836 & 0.8351 \\
\hline & & $K_{d}\left(\mathrm{~d}^{-1}\right)$ & 2.4858 & \\
\hline & & $\mu_{\max }\left(\mathrm{d}^{-1}\right)$ & 2.4820 & 1 \\
\hline & & $K_{s}(\mathrm{mg} / \mathrm{L})$ & -10.7838 & \\
\hline & Comp-2 & $Y(\mathrm{mg} \mathrm{VSS} / \mathrm{mg} \mathrm{COD})$ & 0.1252 & 0.8692 \\
\hline & & $K_{d}\left(\mathrm{~d}^{-1}\right)$ & 3.4184 & \\
\hline & & $\mu_{\max }\left(\mathrm{d}^{-1}\right)$ & 3.4165 & 1 \\
\hline & & $K_{s}(\mathrm{mg} / \mathrm{L})$ & -5.0475 & \\
\hline & Comp-3 & $Y(\mathrm{mg} \mathrm{VSS} / \mathrm{mg} \mathrm{COD})$ & 0.1315 & 0.9344 \\
\hline & & $K_{d}\left(\mathrm{~d}^{-1}\right)$ & 10.8939 & \\
\hline & & $\mu_{\max }\left(\mathrm{d}^{-1}\right)$ & 109.0513 & 1 \\
\hline & & $K_{s}(\mathrm{mg} / \mathrm{L})$ & -5.9978 & \\
\hline & Overall ABR & $Y(\mathrm{mg} \mathrm{VSS} / \mathrm{mg} \mathrm{COD})$ & 0.131451 & 0.9344 \\
\hline & & $K_{d}\left(\mathrm{~d}^{-1}\right)$ & 5.297431 & \\
\hline & & $\mu_{\max }\left(\mathrm{d}^{-1}\right)$ & 5.302227 & 0.9999 \\
\hline & & $K_{s}(\mathrm{mg} / \mathrm{L})$ & -0.41092 & \\
\hline \multirow[t]{7}{*}{ Stover-Kincannon } & Comp-1 & $U_{\max }(\mathrm{g} / \mathrm{L} . \mathrm{d})$ & 2500.00 & 0.4276 \\
\hline & Comp-2 & $U_{\max }(\mathrm{g} / \mathrm{L} . \mathrm{d})$ & 2000.00 & 0.4818 \\
\hline & & $K_{B}(\mathrm{~g} / \mathrm{L} . \mathrm{d})$ & -185.40 & \\
\hline & Comp-3 & $U_{\max }(\mathrm{g} / \mathrm{L} . \mathrm{d})$ & 1250.00 & 0.4182 \\
\hline & & $K_{B}(\mathrm{~g} / \mathrm{L} . \mathrm{d})$ & -59.50 & \\
\hline & Overall ABR & $U_{\max }(\mathrm{g} / \mathrm{L} . \mathrm{d})$ & -24 & 0.5947 \\
\hline & & $K_{B}(\mathrm{~g} / \mathrm{L} . \mathrm{d})$ & 5000 & \\
\hline \multirow[t]{4}{*}{ Second order Grau } & Comp-1 & $k_{2}(1 / \mathrm{d})$ & 0.3761 & 0.9955 \\
\hline & Comp-2 & $k_{2}(1 / \mathrm{d})$ & 0.3981 & 0.9957 \\
\hline & Comp-3 & $k_{2}(1 / \mathrm{d})$ & 0.1498 & 0.9622 \\
\hline & Overall ABR & $k_{2}(1 / \mathrm{d})$ & 0.6060 & 0.9951 \\
\hline
\end{tabular}




\section{References}

[1] Briliantono, E, (03 April 2013) in Bisnis.com, 2013 , JAKARTA, https://ekonomi.bisnis.com/read/20130403/99/ 6455/industri-pangan-pasar-saus-sambalsemakin-pedas.

[2] Fu Zhu, G., Li, J.Z., Wu, P., Jin, H.Z., Wang, Z. (2008). The Performance and Phase Separated Characteristics of an Anaerobic Baffled Reactor Treating Soybean Protein Processing Wastewater. Bioresource Technology, 99: 8027-8033.

[3] Boopathy, R. (1998). Biological Treatment of Swine Waste Using Anaerobic Baffled Reactors. Bioresource Technology, 64: 1-6.

[4] Feng, H., Hua, L., Mahmood, Q., Qiu, C., Fang, C., Shen, D. (2008). Anaerobic Domestic Wastewater Treatment with Bamboo Carrier Anaerobic Baffled Reactor. International Biodeterioration \& Biodegradation, 62: 232-238.

[5] Gopala Krishna, G.V.T., Kumar, P., Kumar, P. (2008). Treatment of Low Strength Complex Wastewater Using an Anaerobic Baffled Reactor (ABR). Bioresource Technology, 99: 8193-8200.

[6] Ghaniyari-Benis, S., Martín, A., Borja, R. (2010). Kinetic Modelling and Performance Prediction of a Hybrid Anaerobic Baffled Reactor Treating Synthetic Wastewater at Mesophilic Temperature. Process Biochemistry, 45: 1616-1623.

[7] Ahamed, A., Chen, C.L., Rajagopal, R., Wua, D., Mao, Y., Ho, I.J.R., Lim, J.W., Wang, J.Y. (2015). Multi-phased Anaerobic Baffled Reactor Treating Food Waste. Bioresource Technology, 182: 239-244.

[8] Hahn, M.J., Figueroa, L.A. (2015). Pilot Scale Application of Anaerobic Baffled Reactor for Biologically Enhanced Primary Treatment of Raw Municipal Wastewater. Water Research, 87: 494-502.

[9] Aqaneghad, M., Moussavi, G. (2016). Electrochemically Enhancement of the Anaerobic Baffled Reactor Performance as an Appropriate Technology for Treatment of Municipal Wastewater in Developing Countries. Sustainable Environment Research, 26: 203-208.

[10] Gulhane, M., Khardenavis, A.A., Karia, S., Pandit, P., Kanade, G.S., Lokhande, S., Vaidya, A.N., Purohit, H.J. (2016). Biomethanation of Vegetable Market Waste in an Anaerobic Baffled Reactor: Effect of Effluent Recirculation and Carbon Mass Balance Analysis, Bioresource Technology, 215: 100109.

[11] von Sperling, M. (2007). Basic Principles of Wastewater Treatment. Volume 2. London SW1H 0QS, UK, IWA Publishing.
[12] Ma, J., Mungoni, L.J., Verstraete, W.W., Carballa, M. (2009). Maximum Removal Rate of Propionic Acid as a Sole Carbon Source in UASB Reactors and the Importance of the Macro- and Micro-Nutrients Stimulation, Bioresource Technology, 100: 3477-3482.

[13] Sumantri, I., Budiyono, B., Purwanto, P. (2017). Performance of Anaerobic Baffled Reactor with Three Compartments in Removal of COD of Wastewater of Chilly Sauce. In Preceeding of the The $2^{\text {nd }}$ International Conference on Energy, Environmental and Information System (ICENIS 2017). Article Number : 03008 , Volume 31 . doi:10.1051/e3sconf/20183103008

[14] APHA. Standard methods for the examination of water and wastewater. (2005) $21^{\text {st }}$ edition. Washington, DC

[15] Abtahi, A.M., Torabian, A., Vosoogh, A., Jafari, B., Gholizadeh, M. (2011). Comparison of the Monod and Kincannon-Stover Models for Kinetic Evaluation in an Anaerobic Baffled Reactor (ABR), Environmental Sciences, 8(2): 55-66

[16] Li, Y., Jin, Y., Li, H., Borion, A., Yu, Z., Li, J. (2018). Kinetic Studies on Organic Degradation and Its Impacts on Improving Methane Production During Anaerobic Digestion of Food Waste. Applied Energy, 213: 136-147.

[17] Yu, Y., (2015). Research on Soybean Protein Wastewater Treatment by the Integrated Two-Phase Anaerobic Reactor, Saudi Journal of Biological Sciences, 22: 526-531

[18] Mekonnen, A., Leta, S., Njau, K.N. (2017). Kinetic Analysis of Anaerobic Sequencing Batch Reactor for the Treatment of Tannery Wastewater, African Journal of Environmental Science and Technology, 11(6): 339-348.

[19] Ebrahimi, A., Hashemi, H., Eslami, H., Fallahzadeh, R.A., Khosravi, R., Askari, R., Ghahramani, E. (2018). Kinetics of Biogas Production and Chemical Oxygen Demand Removal from Compost Leachate in an Anaerobic Migrating Blanket Reactor. Journal of Environmental Management, 206: 707-714.

[20] Abbas, G., Wang, L., Li, W., Zhang, M., Zheng, P. (2015). Kinetics of Nitrogen Removal in Pilot-Scale Internal-Loop Airlift BioParticle Reactor for Simultaneous Partial Nitrification and Anaerobic Ammonia Oxidation. Ecol. Eng. 74: 356-363

[21] Khosravi, R., Shahryari, T., Halvani, A., Khodadadi, M., Ahrari, F., Mehrizi, E.A. (2013). Kinetic Analysis of Organic Matter Removal in Stabilization Pond in the Wastewater Treatment Plant of Birjand. Adv. Environ. Biol. 7: 1182-1188. 
[22] Lee, E., Cumberbatch, J., Wang, M., Zhang, Q. (2016). Kinetic parameter estimation model for anaerobic co-digestion of waste activated sludge and microalgae. Bioresource Technol, 3: 9-17

[23] Stover, E.L., Kincannon, D.F. (1982). Rotating Biological Contactor Scale-Up and Design. 1st International Conference on Fixed Film Biological Processes. Kings Island, Ohio, USA, $1-12$.

[24] Yu, Y. (2015). Research on soybean protein wastewater treatment by the integrated twophase anaerobic reactor. Saudi Journal of Biological Sciences. 22: 526-531

[25] Kreutz, C., Passig, F.H., Carvalho, K.Q., Mees, J.B.R., Gomes, S.D. (2014). Performance of an anaerobic-aerobic reactor and kinetic study of organic matter removal of cattle slaughterhouse effluent. Revista Engenharia Agrícola. 34(2): 341-351. doi:10.1590/S0100691620140002000175

[26] Kusçu, €O.S., Sponza, D.T. (2009). Kinetics of Para-Nitrophenol and Chemical Oxygen Demand Removal from Synthetic Wastewater in an Anaerobic Migrating Blanket Reactor. J. Hazard. Mater. 161: 787-799.
[27] Kosinska, K., Miskiewicz, T. (2009) Performance of an Anaerobic Bioreactor with Biomass Recycling, Continuously Removing COD and Sulphate from Industrial Wastes. Bioresour. Technol. 100: 86-90.

[28] Jafarzadeh, M.T., Mehrdad, N., Hashemian, S.J. (2009). Kinetic Constants of Anaerobic Hybrid Reactor Treating Petrochemical Waste. Asian Journal of Chemistry. 21(3): 1672-1684

[29] Grau, P., Dohanyas, M., Chudoba, J. (1975). Kinetic of Multicomponent Substrate Removal by Activated Sludge. Water Research, 9: 637-642.

[30] Bhunia, P., Ghangrekar, M.M. (2008) Analysis, Evaluation, and Optimization of Kinetic Parameters for Performance Appraisal and Design of UASB Reactors. Bioresour. Technol. 99: 2132-2140. 